\title{
Optimal Food Price Stabilization in a Small Open Developing Country*
}

\author{
Christophe Gouel Sébastien Jean
}

\begin{abstract}
This paper analyzes the use of storage and trade policies to achieve food price stabilization in a small open developing country. Optimal stabilization policies are identified using a rational expectations storage model with risk-averse consumers and incomplete markets. Without public intervention, price dynamics are driven by domestic productive shocks and international prices. On its own, an optimal storage policy is found to be detrimental to consumers because its stabilizing benefits leak to the world market. In contrast, an optimal combination of storage and trade policies results in a powerful stabilization of domestic food prices. However, such an optimal combination is shown to entail two serious drawbacks: its distributive impacts are large compared to its efficiency benefits, and by distorting excess supply curves, it may aggravate high world price episodes.
\end{abstract}

Keywords: food security, incomplete markets, storage, trade policy, export restrictions.

JEL classification: D52, F13, Q11, Q17, Q18.

*This is a pre-copyedited, author-produced PDF of an article accepted for publication in the World Bank Economic Review following peer review. The version of record "Gouel, C. and S. Jean (2015). Optimal Food Price Stabilization in a Small Open Developing Country. World Bank Economic Review, 29(1), 72-101” is available online at: http://dx .doi.org/10.1093/wber/ Iht018.

Christophe Gouel (corresponding author) is junior researcher at INRA, Économie Publique, and research associate at CEPII; his email address is cgouel@grignon.inra.fr. Sébastien Jean is director of CEPII and senior scientist at INRA, Économie Publique; his email address is sebastien.jean@ @ cepii.fr. We would like to thank Jean-Marc Bourgeon, Édouard Challe, Christopher Gilbert, Michel Juillard, Will Martin and Brian Wright for helpful comments. A supplemental appendix to this article is available at http://wber.oxfordjournals.org/. 
In developing countries, staple foods frequently account for a significant share of poor households' budgets. Many poor people have a limited ability to insure against adverse price shocks. Price spikes are problematic for poor households that are not self-sufficient, and these spikes often jeopardize these households' ability to feed themselves. One important response by developing country governments to this concern is the implementation of food price stabilization policies. However, the study of these policies has primarily been confined to closed economy contexts with an emphasis on the role of storage (see Wright 2001, for a survey). From a theoretical standpoint, little is known about the role of trade policy in price stabilization programs, despite the widespread use of these policies. Recourse to trade policy to counter price volatility has been common in most Asian countries, where stabilizing the domestic price of rice is a central objective (Dorosh 2008; Islam and Thomas 1996; Timmer 1989). Trade policies are also used in Middle Eastern and African countries in the case of wheat and, to a lesser extent, maize and rice (Dorosh 2009; Wright and Cafiero 2011). The problem may be less acute in Latin America, where most countries are net exporters of grains, but it is not irrelevant, as evidenced by Chile's use of a price-band system for wheat and other food products (Bagwell and Sykes 2004). More generally, based on a large-scale database of agricultural price distortions, Anderson and Nelgen (2012) show that countries tend to vary their nominal rates of assistance to agriculture to limit the effects of variations in the world prices on the domestic prices.

Trade and trade policies are key aspects that must be considered when examining food security and price stabilization in developing countries. These policies raise numerous questions, the most important of which may be how storage and trade policies should be combined to achieve price stabilization. Increased reliance on national buffer stocks is frequently suggested as a remedy for developing countries faced with significant volatility in world prices. Are buffer stocks a consistent policy per se, independent of trade policy interventions? Dorosh (2008) suggests that greater reliance on the world market allowed much more cost-effective price stabilization in Bangladesh than in India; the latter relied almost exclusively on huge public stocks and severe restrictions on imports. Can it be assumed that greater trade openness, or a more reactive trade policy, will reduce the level of stocks needed to achieve a given stabilization target, and to what extent can this be expected to occur?

Export restrictions raise a number of additional questions. Most analysts of the 2007-08 food crisis agree that trade policies played a significant role in fueling the international price spikes (Braun 2008; Headey 2011; Mitra and Josling 2009). In particular, the export bans enforced by several rice exporters appear to have contributed greatly to the astonishing price levels that were reached (Slayton 2009). Noting the similar situation in the 1973-74 crisis, Martin and Anderson (2012) emphasize the collective action problem created by export restrictions: the use of these restrictions by some countries to provide shelter from price spikes aggravated the problem for others (see also Bouët and Laborde Debucquet 2012). The restrictions imposed by Russia on cereal exports following a drought in 2010 only add to this concern. A first step toward managing this problem is to achieve a better understanding of the motivations and consequences of export restrictions. Based on a Marshallian surplus analysis, many authors conclude that such policies are harmful to the countries that enact them. Do these policies really cause harm, or do export restrictions make economic sense for a small open economy? In the latter case, is refraining from imposing export restrictions an important sacrifice for the country concerned? Would specific flanking policies be preferable?

Many studies have examined how uncertainty affects trade theory results, as discussed in the next section. However, a characteristic of staple food products is that they are storable, which is not considered in most of these works. Storage and its consequences are the subject of a separate strand of the literature, which includes some analyses of the relationships among storage, trade, and trade policy. Although several cases have been studied, these studies do not identify the optimal policies. In contrast, the present paper proposes an optimal stabilization policy design for a small open economy within a rational expectations storage model 
using tools developed for the analysis of optimal dynamic policies. The focus is on food security concerns in developing countries, assuming that consumers are risk averse with no insurance possibilities and assuming a country that is self-sufficient, on average.

This policy design is challenging because the combination of rational expectations and non-negative storage and trade constraints renders the model (which does not admit closed-form solutions) problematic to solve and even more difficult to optimize along a dynamic path. Achieving model tractability and identifying stylized results requires some simplifications. For this reason, we focus on consumers' risk aversion, which is linked most directly to food security concerns, and overlook producers' risk aversion. A significant proportion of poor farmers in developing countries are actually net buyers of food (World Bank 2007), and therefore, their aversion is more akin to consumers' than producers' risk aversion. We also disregard supply reaction, which is a potentially important mechanism but is usually of limited quantitative importance over the time frame of a price surge. Furthermore, in the interest of simplicity, we work with a single-country model. To obtain initial insights into the export restrictions issue, we assess the consequences for developing countries of refraining from imposing such restrictions. For the sake of brevity, the paper focuses exclusively on storage and trade policies, although social assistance programs are also key policy instruments for addressing the consequences of food price volatility. However, we leave their analysis in a comparable framework for future work (see Larson, Lampietti, Gouel, Cafiero, and Roberts 2014, for a comparison of a storage policy with safety nets).

\section{Trade, uncertainty, and storage: Related literature}

Uncertainty is widely understood to potentially affect the main conclusions of trade theory. David Ricardo (1821, Ch. 19) concluded that temporary tariffs on cereals might be justified to avoid large losses to farmers who after increasing their production, and so the required capital, to face a sudden change in trade, such as wars, would suffer greatly from an immediate return to the situation prevailing before the crisis. The first formalization of this issue was achieved by Brainard and Cooper (1968). Based on a portfolio approach, these authors show that diversification in a primary producing country decreases fluctuations in national income, which increases national welfare if the country is risk averse. Based on a comparable framework that includes risk aversion in a context in which productive choices are made before uncertainty is resolved, several other papers challenge the idea of the optimality of free trade under uncertainty (Anderson and Riley 1976; Batra and Russell 1974; Turnovsky 1974).

Helpman and Razin (1978) point out that this result hinges crucially on the assumption of incomplete risk-sharing markets. These authors show that the main results of the Ricardian and Heckscher-Ohlin theories of international trade, including the optimality of free trade, carry over to uncertain environments if the risk can be shared appropriately. In their model, risk is shared because the stock market allows households to diversify their capital, and the cross-border trade in financial assets opens the possibility for international risk-sharing arrangements.

Helpman and Razin's seminal contributions clarify the conditions underlying the potential deviations from standard results and pave the way for insightful elaborations. Yet, there are many reasons why the conditions required for their results might not hold. For instance, households may need to invest their capital in a particular activity without any possibility of diversification to insure against or to trade the corresponding risk. In this context, which is particularly plausible for rural households in developing countries, Eaton and Grossman (1985) show that the optimal trade policy for a small open economy is not free trade. On average, the optimal policy entails an anti-trade bias. Similar conclusions emerge if market incompleteness 
is the result of a lack of international trade in financial assets (Feenstra 1987). In a specific-factor model with risk-averse factor owners, Cassing, Hillman, and Long (1986) show that a state-contingent tariff policy can increase the expected utility of all agents. Newbery and Stiglitz (1984) provide another illustration of the potential insurance role of trade restrictions, extending the analysis to a two-country model. Without insurance markets, Newbery and Stiglitz show that free trade may be Pareto inferior to no trade. Indeed, autarky directly links domestic prices to domestic output, thus providing perfect income insurance for farmers for a unitary price elasticity of demand.

These cases show that a departure from free trade may be motivated by risk-sharing objectives when other arrangements are not available. ${ }^{1}$ When addressing food security in developing countries, it appears to be reasonable to assume incomplete insurance markets. Poor households have little opportunity to insure against the real income risk associated with variable food prices, and poor farmers (as well as many other poor workers) cannot diversify their income source, at least in the short run. Because we focus on food security in a developing country, we adopt this assumption of market incompleteness and assume that consumers are risk averse, with no insurance schemes available.

Addressing food security requires accounting for the fact that staple food products are storable. Storability is especially important because storage is a central feature of these markets and can be considered an intertemporal risk-sharing arrangement. Studies of food security have long regarded storage as a key feature. Early analyses of storage-trade interactions relied upon idealized or arbitrary storage technologies (Bigman and Reutlinger 1979; Feder, Just, and Schmitz 1977; Pelcovits 1979; Reutlinger and Knapp 1980). Although these are useful to ensure tractability, such simplified representations that are not rooted in a consistent description of agent behavior do not accurately reflect the risk-sharing properties of storage. These representations are also vulnerable to the Lucas critique, to the extent that the consequences of policies on agents' expectations are not taken into account. Hence the interest in a rational expectations, infinite-horizon framework.

In addition to specific analyses of oil-related problems, in which world prices are the primary source of uncertainty (Teisberg 1981; Wright and Williams 1982b), storage-trade interactions were first studied in a rational expectations, infinite-horizon framework by Williams and Wright (1991, Ch. 9), who consider a small open market to be the extreme case in a two-country model. ${ }^{2}$ Srinivasan and Jha (2001) model Indian agricultural markets in relation to the world. They consider the rice market, for which India is a large country, and the wheat market, for which India is a small country. In both markets, there are competitive private storers. World prices are randomly generated without accounting for serial correlation. The authors find that international trade is stabilizing even when the international price is more volatile than the domestic price. Brennan (2003) considers the Bangladesh rice market and shows that opening the market to trade is as stabilizing as some public policies (such as subsidies to private storage or a price ceiling) and has no fiscal cost. In all of these studies, welfare is measured by changes in surpluses. In contrast to the theoretical analyses of trade under uncertainty mentioned previously, these storage-trade models focus on the assessment of given exogenous policies. The models provide no hints of what the optimal policy might be. The present paper extends the normative analyses of trade theory in an uncertain environment to an intertemporal framework

\footnotetext{
${ }^{1}$ It is worth noting that Dixit $(1987,1989)$ criticizes the idea that the absence of insurance markets provides a rationale for trade policy when incomplete markets result from informational problems.

${ }^{2}$ Miranda and Glauber (1995) confirm Williams and Wright's results and propose an improved numerical method. Makki, Tweeten, and Miranda (1996, 2001) present a policy application of this model. Based on a three-country model that includes the EU, the US, and the rest of the world, they analyze the effects of removing current policy distortions such as export subsidies. Coleman (2009) extends Williams and Wright's work by considering that trade takes time; the time to ship provides a new motive for stockpiling.
} 
with storage under rational expectations. Because it is very difficult to design optimal policies in a dynamic setting, we consider a single-country model. We follow Williams and Wright's insight and represent the world price as generated by a storage model, and we consider it to be exogenous to the country. ${ }^{3}$

\section{The model}

We consider the market for a storable commodity in a small open economy. The world price is taken as given, and the per-unit transport cost is constant. Consumers are risk averse, and domestic food price volatility is driven by random output and a stochastic world price. Production is defined by exogenous stochastic shocks, so producers are not represented explicitly but are introduced later, when we account for the effect of the policies on their welfare.

\section{Consumers}

The economy is populated with risk-averse consumers whose final demand for food has an isoelastic specification: $D\left(P_{t}\right)=d P_{t}^{\alpha} Y^{\eta}$, where $d>0$ is a parameter of normalization; $P_{t}$ is the period $t$ price; and $\alpha$, with $\alpha<0$ and $\alpha \neq-1$, and $\eta \neq 1$ are the price and income elasticities, respectively. Income, $Y$, is assumed to be constant over time, which limits the number of state variables and allows a diagrammatic exposition of the results. Assuming that there are only two goods and that the second good is the numeraire, the integration of this demand function provides the following instantaneous indirect utility function (Hausman 1981):

$$
\hat{v}\left(P_{t}, Y\right)=\frac{Y^{1-\eta}}{1-\eta}-d \frac{P_{t}^{1+\alpha}}{1+\alpha} .
$$

This utility function has a relative risk aversion equal to the income elasticity of demand. To distinguish income elasticity from risk aversion, we follow Helms (1985a); we assume $\hat{v}\left(P_{t}, Y\right)$ to be positive and apply a monotone transformation to the indirect utility function:

$$
v\left(P_{t}, Y\right)=\frac{\left[\hat{v}\left(P_{t}, Y\right)\right]^{1+\theta}}{1+\theta}
$$

with $v\left(P_{t}, Y\right) \rightarrow \ln \hat{v}\left(P_{t}, Y\right)$ as $\theta \rightarrow-1$. This specification remains consistent with the isoelastic demand function, but its coefficient of relative risk aversion is

$$
\rho\left(P_{t}, Y\right)=\eta-\theta \frac{Y^{1-\eta}}{\hat{v}\left(P_{t}, Y\right)},
$$

with $\theta$ indexing the degree of risk aversion.

For simplicity, the representative consumer is assumed to adopt hand-to-mouth behavior: he consumes current income and does not save to smooth out fluctuations. The dynamics are thus simplified because the consumer's "cash on hand" does not have to be included as a state variable. This assumption overlooks the role of self-insurance through saving. However, this self-insurance remains limited in practice and falls short of providing protection comparable to that delivered by a complete market due, inter alia, to borrowing

\footnotetext{
${ }^{3}$ Country-level policies of price insulation might influence the formation of world prices (Martin and Anderson 2012), but this is difficult to account for in the present framework.
} 
constraints and to the rather large share of the budget accounted for by staple food in many developing countries, especially for poor households.

Given the absence of saving, the consumer does not solve an intertemporal problem. At each period, he is concerned only with current-period demand, which is not affected by the degree of risk aversion. The spatial and intertemporal arbitrages made by traders and storers are thus independent of consumer risk aversion because the demand function is independent of the degree of risk aversion. This independence creates the need for public intervention.

\section{Storers}

The single representative speculative storer is assumed to be risk neutral and to act competitively. Storage allows a commodity to be transferred from one period to the next. Storing the quantity $S_{t}$ from period $t$ to period $t+1$ entails a purchasing cost, $P_{t} S_{t}$, and a storage cost, $k S_{t}$, with $k$ representing the unit physical cost of storage. A (positive or negative) per-unit subsidy $\zeta_{t}$ for private storage is also considered. The benefits in period $t$ are the proceeds from the sale of previous stocks: $P_{t} S_{t-1}$. The storer maximizes his expected profit as stated by the following sum of cash flows:

$$
\max _{\left\{S_{t+i} \geq 0\right\}_{i=0}^{\infty}} \mathrm{E}_{t}\left\{\sum_{i=0}^{\infty} \beta^{i}\left[P_{t+i} S_{t+i-1}-\left(P_{t+i}+k-\zeta_{t+i}\right) S_{t+i}\right]\right\},
$$

where $\mathrm{E}_{t}$ denotes the mathematical expectations operator conditional on information available at time $t$, and $\beta$ is the discount factor. Accounting for the possibility of a corner solution (i.e., the non-negativity constraint of storage), the first-order condition of this problem yields the following complementary condition: ${ }^{4}$

$$
S_{t} \geq 0 \quad \perp \quad \beta \mathrm{E}_{t}\left(P_{t+1}\right)+\zeta_{t}-P_{t}-k \leq 0,
$$

which means that the inventories are null when the marginal cost of storage is not covered by the expected marginal benefits; for positive inventories, the arbitrage equation holds with equality. Thus, the storer buys when the present prices are sufficiently low compared to their expected future level.

\section{International trade}

Because the model describes a homogeneous product for a small open economy, international trade modeling collapses to two arbitrage conditions: the domestic price, on the one hand, and the export or import parity price, on the other hand. These equations are expressed in complementarity form as follows:

$$
\begin{array}{ccc}
M_{t} \geq 0 & \perp \quad P_{t}-v_{t}^{M}-\left(P_{t}^{w}+\tau\right) \leq 0, \\
X_{t} \geq 0 & \perp \quad\left(P_{t}^{w}-\tau\right)-P_{t}-v_{t}^{X} \leq 0,
\end{array}
$$

where $M_{t}$ and $X_{t}$ are imports and exports; $P_{t}^{w}$ is the world price; and $\tau$ represents the per-unit import and export costs, which are assumed to be constant and identical. $v_{t}^{M}$ and $v_{t}^{X}$ denote (positive or negative) per-unit

\footnotetext{
${ }^{4}$ Complementarity conditions in what follows are written using the "perp" notation $(\perp)$. This notation means that both inequalities must hold, and at least one must hold with equality.
} 
taxes on imports and exports. The complementarity equations for trade (6)-(7) imply that the domestic price is restricted to evolving in a moving band defined by the world price, trade costs, and trade taxes, if any:

$$
P_{t}^{w}-\tau-v_{t}^{X} \leq P_{t} \leq P_{t}^{w}+\tau+v_{t}^{M} .
$$

\section{Recursive equilibrium}

The period $t$ harvest is denoted $\varepsilon_{t}^{H}$ and is an i.i.d. random variable. The model has three state variables: $S_{t-1}$, $\varepsilon_{t}^{H}$, and $P_{t}^{w}$. In any time period, the first two can be combined into one variable, availability $\left(A_{t}\right)$, which is the sum of production and private carry-over:

$$
A_{t}=S_{t-1}+\varepsilon_{t}^{H}
$$

The other state variable, the world price, follows a continuous Markov chain, defined in the next section and characterized by the following transition function:

$$
P_{t+1}^{w}=f\left(P_{t}^{w}, \varepsilon_{t+1}^{w}\right),
$$

where $\varepsilon^{w}$ is the random production in the world market, which is assumed to be uncorrelated with domestic production shocks. ${ }^{5}$

The market equilibrium can be written as follows:

$$
A_{t}+M_{t}=D\left(P_{t}\right)+S_{t}+X_{t}
$$

Based on the above, we can define the recursive equilibrium of the problem without public intervention:

Definition. In the absence of a stabilization policy (i.e., $\zeta_{t}=v_{t}^{M}=v_{t}^{X}=0$ ), a recursive equilibrium is a set of functions, $S\left(A, P^{w}\right), P\left(A, P^{w}\right), M\left(A, P^{w}\right)$, and $X\left(A, P^{w}\right)$, defining private storage, price, import, export over the state $\left\{A, P^{w}\right\}$, and transition equations (9)-(10) such that (i) the storer solves (4), (ii) trade obeys the arbitrage equations (6)-(7), and (iii) the market clears.

\section{World price}

Modeling world price dynamics is a crucial issue. The world price level directly influences the domestic price through arbitrage with export and import parity prices. Furthermore, by influencing storage decisions and domestic price expectations, which are central to the issues considered here, the world price may also affect expectations about the future price level.

In single-country models, the world price is generally represented as a stochastic process following a standard distribution, in some cases including first-order autocorrelation (Brennan 2003; Srinivasan and Jha 2001). These types of simplifications are not consistent with the stylized facts on agricultural prices (Deaton and Laroque 1992), which appear to be correctly represented by a storage model (Cafiero, Bobenrieth, Bobenrieth, and Wright 2011). Taking full account of this storage-based representation of world prices would require a two-country model, in which the rest of the world is modeled alongside the economy being studied. The complexity cost of such an option would be high and difficult to reconcile with our objective of

\footnotetext{
${ }^{5}$ It would not be difficult to allow for correlated production shocks, if needed.
} 
identifying the optimal policies. Following Williams and Wright (1991, Ch. 9), a way out of this dilemma would be to consider the small open economy model as a limit case of a two-country model as the size difference between the two countries increases. In this limit case, the small economy is negligible compared to the large one, meaning that the rest of the world can be modeled without paying attention to the small economy under study. In other words, overlooking the influence of the economy on the world market allows the world prices to be modeled as a separate process that is exogenous from the economy's point of view. This assumption of a price-taker economy allows us to disregard the motivations that are linked to the influence of government decisions on world markets and greatly simplifies the analysis.

World prices are thus assumed to result from a storage model with random inelastic production. They are set as a result of a system of three equations equivalent to (5), (9), and (11), without import and export variables and without storage subsidy. This system has one state variable: availability. All variables and functions corresponding to the world market are indicated with the superscript $w$. Given the model's structure, the observation of price allows us to define the state of the system; price dynamics can thus be defined as a continuous state Markov chain. The expression can be derived using equation (9) and the decision rules, $P^{w}\left(A^{w}\right)$ and $S^{w}\left(A^{w}\right)$, which provide the following:

$$
\begin{aligned}
P_{t+1}^{w} & =P^{w}\left(A_{t+1}^{w}\right) \\
& =P^{w}\left(S^{w}\left(A_{t}^{w}\right)+\mu \varepsilon_{t+1}^{w}\right) \\
& =P^{w}\left(S^{w}\left(\left(P^{w}\right)^{-1}\left(P_{t}^{w}\right)\right)+\mu \varepsilon_{t+1}^{w}\right),
\end{aligned}
$$

from which equation (10) follows. $\mu$ is a scale parameter that allows a shift in the world yield distribution.

We want to focus on economic mechanisms independent of structural differences between the economy and the rest of the world, so we consider a perfectly symmetrical situation in which the world market is calibrated with the same parameter values as the domestic country (thus in the benchmark calibration $\mu=1$ ). Given that we consider an asymptotic situation in which the rest of the world is infinitely larger than the country, trade does not affect the world equilibrium, and the calibration does not need to account for any size difference. The symmetry between the rest of the world and the economy may appear to be arbitrary. For instance, the diversification of risks across the many countries that are part of the rest of the world could be assumed to lead to a lower variability of output. If the rest of the world is richer on average than the country considered, it could also be argued that price elasticity should be assumed to be smaller in the rest of the world. This assumption would make sense, although the symmetry assumption adopted here means that international trade is not motivated by a structural difference but only by the existence of country-specific production shocks that are uncorrelated to worldwide shocks. The sensitivity of the results to the assumption of self-sufficiency, and thus to the symmetry between the country and the world market, is analyzed in a supplemental appendix (section S4, available at http://wber .oxfordjournals .org/).

\section{Calibration}

The rational expectations storage model does not allow a closed-form solution; it must be approximated numerically. The numerical algorithm that we use is based on a projection method and is described in detail in the supplemental appendix.

The parameters are set such that at the non-stochastic steady-state equilibrium, price, production, consumption, and availability are equal to 1 , and imports and exports are equal to 0 (see table 1 for parameter values). As a result, the country is self-sufficient in the steady state, and no trade takes place. 
Table 1: Parameterization

\begin{tabular}{llc}
\hline Parameter & Economic interpretation & Assigned value \\
\hline$\beta$ & Annual discount factor & 0.95 \\
$\eta$ & Income elasticity & 0.5 \\
$\alpha$ & Own-price demand elasticity & -0.4 \\
$\gamma$ & Commodity budget share & 0.15 \\
$Y$ & Income & 6.67 \\
$d$ & Normalization parameter of demand function & 0.39 \\
$\theta$ & Parameter defining risk aversion & -2.62 \\
$k$ & Physical storage cost & 0.06 \\
$\tau$ & Trade cost & 0.2 \\
$\mu$ & Normalization parameter of world yield distribution & 1 \\
$\varepsilon^{H}, \varepsilon^{w}$ & Probability distribution of yield & $B(2,2) \cdot 0.5+0.75$ \\
\hline
\end{tabular}

An annual interest rate of 5\% is used for discounting. Based inter alia on Korinek and Sourdin (2010), we set trade costs to $20 \%$. This cost is more than the average cost cited in this study for agricultural products, reflecting our focus on grains for poor countries. ${ }^{6}$

Seale and Regmi (2006) estimate elasticities for food consumption for 144 countries. From their research, we choose cereal elasticities that are typical of low-income countries: -0.4 for price elasticity and 0.5 for income elasticity. We assume that consumers spend, at the steady state, $\gamma=15 \%$ of their income on the staple, an intermediate value between what is observed for rice consumption in poor and affluent households in Asia (Asian Development Bank 2008). Because steady-state consumption and price are equal to 1, income, which is assumed to be constant, is equal to the inverse of the commodity budget share, $1 / \gamma$. At the steady state, we assume a relative risk aversion parameter of 2, implying $\theta=-2.62$.

We follow Brennan (2003) and assume a per-unit storage cost of $6 \%$ of the steady-state price (i.e., $k=0.06$ ). Combined with the opportunity cost, this physical storage cost entails an overall storage cost at the steady state equal to $11.3 \%$ of the steady-state price. For the yield at a country level, we assume that the random productions, $\varepsilon^{H}$ and $\varepsilon^{w}$, follow a beta distribution. The beta distribution has the advantage of being empirically supported and popular in stochastic yield modeling at a local level (see, among others, Babcock and Hennessy 1996; Nelson and Preckel 1989) and of having bounded support, which is computationally convenient. We assume that the distribution has shape parameters 2 and 2, which makes it unimodal at 0.5, and we assume that it is symmetric. The distribution is translated and rescaled to vary between 0.75 and 1.25 , implying a coefficient of variation of $11.2 \%$.

\section{Dynamics without public policy}

To understand the consequences of public policies, the situation without public intervention is a natural and useful benchmark. Because the model used here differs significantly from those discussed in the literature so far, we analyze this benchmark case in some detail. ${ }^{7}$ Stock, price, and trade behavior as a function of

\footnotetext{
${ }^{6}$ International trade also frequently entails above-average domestic transport costs.

${ }^{7}$ The effects of different trade and storage costs in the situation without public intervention are discussed in the working paper version of this article (Gouel and Jean 2012).
} 
availability are represented in figure 1(a) for four different values of the world price. Figure 1 also includes similar representations for situations with policy intervention in panels (b)-(d), which we discuss below.

To understand this figure, first consider the central panel, where domestic price is represented as a function of availability. The demand function with no storage and no trade, represented in light gray, is a useful benchmark. Consider, for example, the solid black line, corresponding to a world price equal to 0.9. When availability is lower than 1 by at least $3 \%$, the domestic price is equal to 1.1: storage is zero (see left panel for storage behavior), and the country imports at an import parity price (1.1) that is equal to the world price (0.9) plus transport costs (0.2). Conversely, when availability is large enough (in this case, when it exceeds 1 by at least $2 \%$ ), the domestic price is higher than the demand schedule would imply because of storage. No trade occurs in this case (see right panel for trade behavior), given that the domestic price is consistently above the export parity price $(0.7$, in this case).

More generally, for this small open economy without any trade taxes, domestic prices necessarily lie in a moving band defined by world prices plus or minus trade costs. Compared to a closed economy, this context radically modifies storage behavior and its consequences. Abundant availability usually favors storage, but exporting is another potential profitable outlet; when scarcity prevails, the stabilizing effect of selling inventories may be redundant in the face of the price ceiling imposed by import competition.

The first salient feature is that there is no storage when the country imports (see figure 1(a)). To see why this case is necessarily true, note that the domestic price is exactly equal to the world price plus trade costs when the country imports. Equation (5) can thus be rewritten as follows:

$$
\beta \mathrm{E}_{t}\left(P_{t+1}\right)-P_{t}-k=\beta \mathrm{E}_{t}\left(P_{t+1}\right)-P_{t}^{w}-\tau-k .
$$

Because the storage arbitrage condition (5) holds for the rest of the world (as assumed here, given how world prices are determined),

$$
-P_{t}^{w}-k \leq-\beta \mathrm{E}_{t}\left(P_{t+1}^{w}\right)
$$

which, combined with (15), gives

$$
\beta \mathrm{E}_{t}\left(P_{t+1}\right)-P_{t}-k \leq \beta \mathrm{E}_{t}\left(P_{t+1}-P_{t+1}^{w}\right)-\tau .
$$

Given (8), the domestic price is always inferior or equal to the import parity price, which also holds in expectations terms. As a result,

$$
\beta \mathrm{E}_{t}\left(P_{t+1}\right)-P_{t}-k \leq(\beta-1) \tau<0 .
$$

This equation implies that domestic storage is not profitable when importing because the expected value of next year's difference between domestic and world prices cannot exceed trade costs.

This feature, emphasized inter alia by Williams and Wright (1991) in a two-country framework, reflects the fact that importing for storage never makes economic sense when intertemporal arbitrage is the same at home and abroad. It is always preferable to defer the decision about whether importing will be necessary until the next year.

Storage and exports may coexist in cases where availability is relatively abundant. When the country exports, the domestic price equals the export parity price, and the storage arbitrage equation becomes

$$
S_{t} \geq 0 \quad \perp \quad \beta \mathrm{E}_{t}\left(P_{t+1}\right)-P_{t}^{w}+\tau-k \leq 0 .
$$



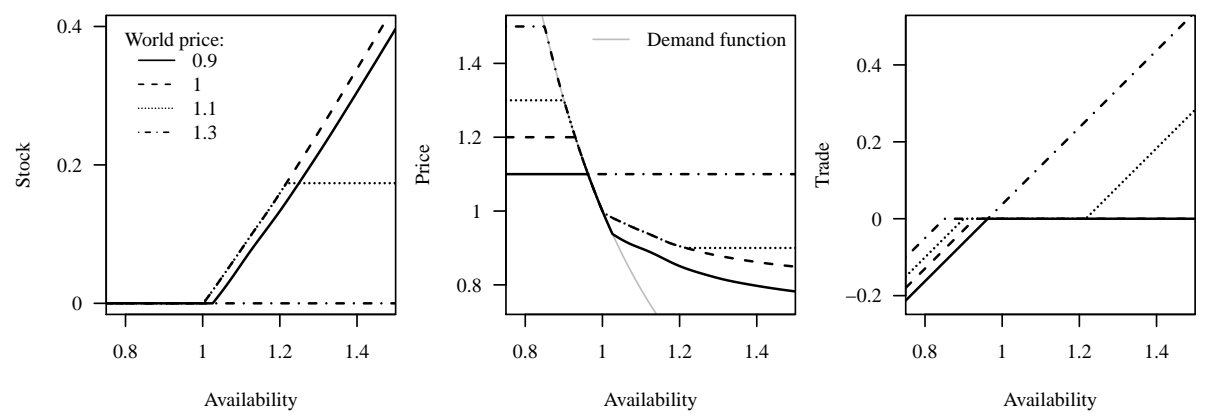

(a) Without public intervention
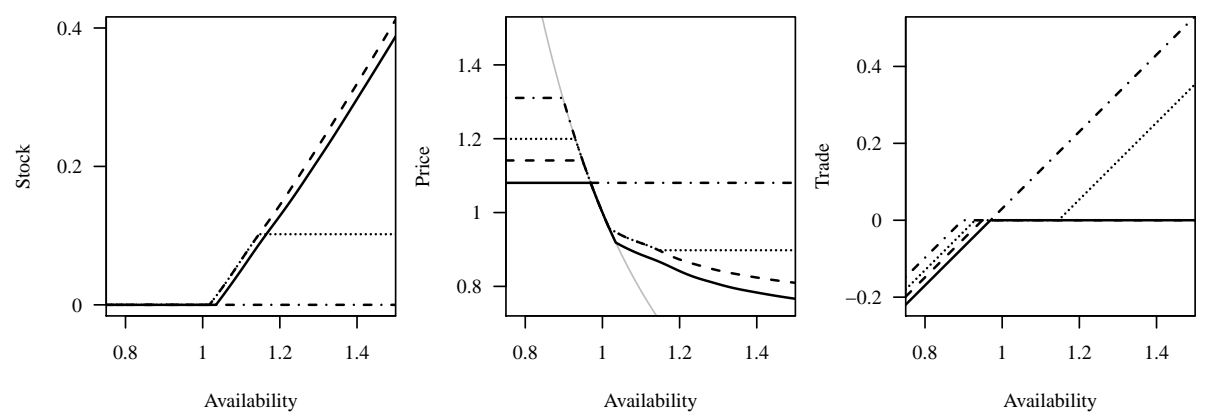

(b) Optimal trade policy
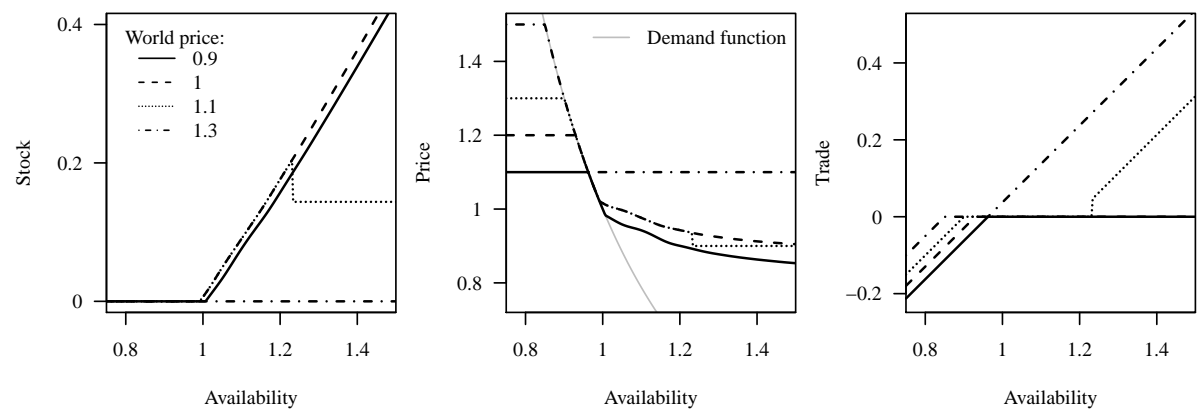

(c) Optimal storage subsidy
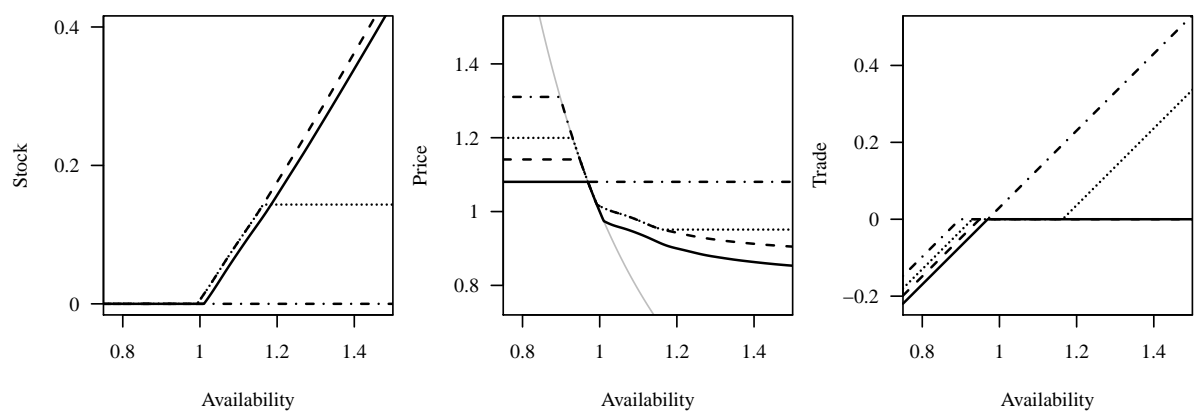

(d) Optimal policy with both instruments

Figure 1: Stock, price and trade behavior. Negative trade values refer to imports. The gray curve in the central panels refers to the demand schedule with no storage and no trade. 
For a sufficiently high world price, the expected domestic price cannot be high enough to make speculative storage profitable; exporting is more profitable than storing, and no storage takes place. The coexistence of storage and exports is only observed for intermediate world price levels that are high enough compared to domestic prices to make exporting profitable but not high enough to make the first unit of storage less profitable than exporting. ${ }^{8}$ The interrelations between storage and exports are also illustrated by the storage rule (left panel of figure 1(a)) for a world price equal to 1.1, where exports are reflected in a flat storage curve for relatively large availabilities. For a world price equal to 1.3, exporting is always more profitable than storing, so the storage rule is flat throughout.

The current world price affects domestic storage even in the absence of trade. Indeed, world prices are positively autocorrelated because they are generated by a storage model. As a result, a higher current world price entails higher world price expectations for the next period. Accordingly, storage outside of trade situations moves slightly upward for higher world prices. This relationship is illustrated in figure 1(a) by the two situations of a world price equal to 0.9 and 1. In both cases, the world price is too low to make exports profitable. For availability above the steady state, storers accumulate stocks, but stock levels are higher for a world price of 1 than for a world price of 0.9 because of the expectation of higher future world prices, which increases the profitability of storage. This increased profitability also translates into higher domestic prices for a world price of 1 because of the increased stock accumulation.

Under the assumption of a small economy, exporting implies a complete disconnect between domestic prices and availability, as reflected in the flat segments of the price curves that are observed for large enough availabilities for world prices equal to 1.1 and above in the central panel of figure 1(a). Similarly, for limited availabilities, the domestic price is disconnected from availability when it reaches the import trigger price, which is equal to the world price plus trade costs. Between these two cases, the price curve takes a standard form in the presence of storage, with a strongly downward sloping curve for availabilities below a given threshold under which no storage takes place and a smoother curve thereafter. For trade, assuming exogenous world prices implies that the net trade curve has a unitary slope whenever trade is not zero.

A sample simulation of world and domestic prices illustrates the link between them (figure 2). The domestic price tends to be set to the import parity price when the world price is low and to the export parity price when the world price is high. Most world price spikes are imported through trade to the domestic market.

\section{Optimal stabilization policy}

When modeling the relationships between storage and trade policies, we do not want to only analyze specific cases; we also want to assess the optimal use of these policies. To perform this assessment, we assume that the government cannot commit to future policies and must follow time-consistent policies. To design this optimal stabilization policy, we need to formulate a meaningful objective. The optimization problem of the discretionary optimal policy can then be stated.

\section{Social welfare function}

Policy design is usually based on maximizing the sum of all agents' surpluses. This standard practice is not valid here because the expected surplus is not a suitable measure of risk-averse consumers' welfare. Helms

\footnotetext{
${ }^{8}$ The returns to storage are declining due to its negative influence on expected future domestic prices.
} 


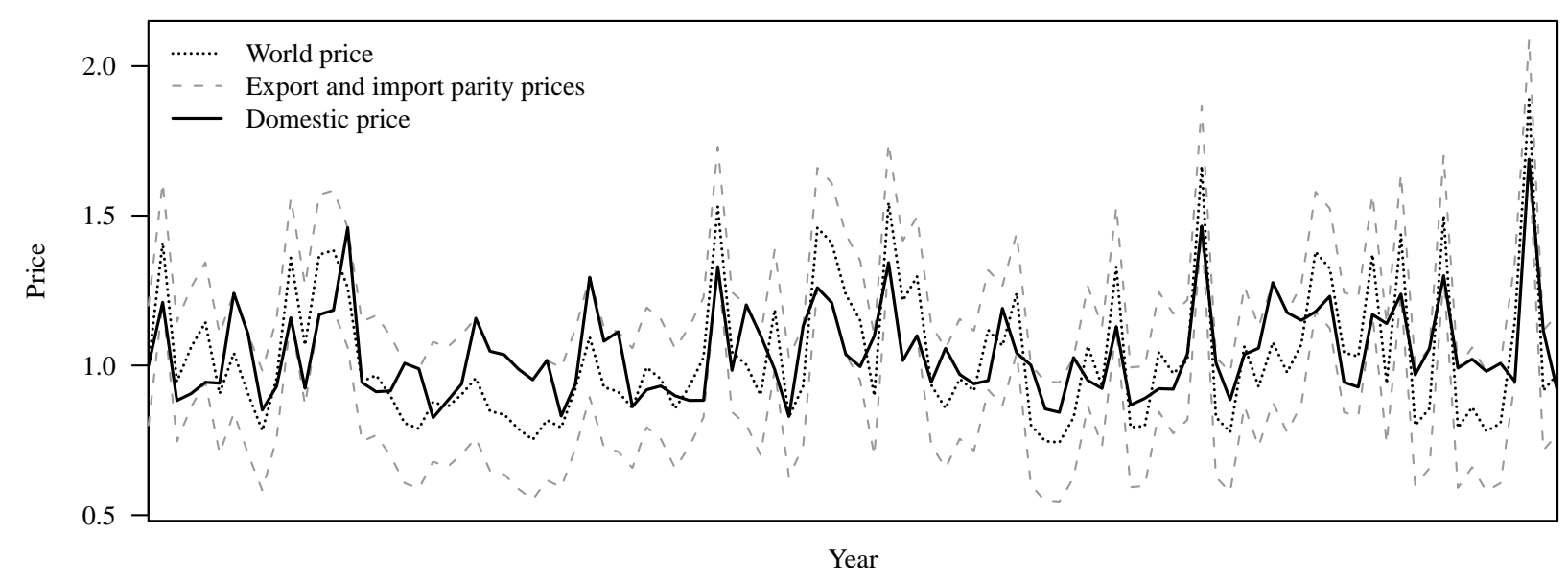

Figure 2: Simulated history of prices without public intervention

(1985b) shows that, in contrast, the ex ante equivalent variations are meaningful welfare indicators. This corresponds to the amount of income that, in the price regime without intervention, would bring the same change in expected utility as the intervention considered here. In the intertemporal framework used in this paper, in which savings are not taken into account, the temporal allocation of this equivalent income is not neutral. ${ }^{9}$ Assuming that equivalent variation takes the form of a constant income flow, the corresponding amount $E V_{t}$ is implicitly defined at period $t$ by

$$
\mathrm{E}_{t}\left\{\sum_{i=0}^{\infty} \beta^{i}\left[v\left(\tilde{P}_{t+i}^{t}, Y+E V_{t}\right)-v\left(P_{t+i}, Y\right)\right]\right\}=0,
$$

where $\tilde{P}_{t+i}^{t}$ refers to the price in period $t+i$ when the policy intervention is stopped from $t$ onward. A first-order Taylor series expansion of the first term around the path followed without further intervention gives

$$
E V_{t} \approx \frac{1-\beta}{w_{t}} \mathrm{E}_{t} \sum_{i=0}^{\infty} \beta^{i}\left[v\left(P_{t+i}, Y\right)-v\left(\tilde{P}_{t+i}^{t}, Y\right)\right]
$$

where $w_{t}=(1-\beta) \mathrm{E}_{t} \sum_{i=0}^{\infty} \beta^{i} v_{Y}\left(\tilde{P}_{t+i}^{t}, Y\right)$ is the discounted average of the future marginal utility of income in expected terms. Social welfare can be measured by combining this ex ante equivalent variation for consumers with the surplus of other agents: ${ }^{10}$

$$
\begin{aligned}
W_{t} & =\frac{1}{w_{t}} \mathrm{E}_{t} \sum_{i=0}^{\infty} \beta^{i}\left[v\left(P_{t+i}, Y\right)-v\left(\tilde{P}_{t+i}^{t}, Y\right)\right] \\
& +\mathrm{E}_{t} \sum_{i=0}^{\infty} \beta^{i}\left[P_{t+i} \varepsilon_{t+i}^{H}+P_{t+i} S_{t+i-1}-\left(P_{t+i}+k-\zeta_{t+i}\right) S_{t+i}-\text { Cost }_{t+i}\right],
\end{aligned}
$$

where Cost $_{t+i}$ denotes the period $t+i$ fiscal cost of public policies.

\footnotetext{
${ }^{9}$ Gollier (2010) shows, in a different context, how savings behavior ensures equivalence between alternative patterns of allocation of replacement income over time.

${ }^{10}$ Note that if income elasticity and relative risk aversion were equal to zero, this definition would make $w_{t}$ equal to 1 so that the social welfare function would actually be the classic sum of the surpluses.
} 
We neglect the distortionary cost caused by revenue collection, so the fiscal cost of policy intervention is the cost of subsidizing private storage plus the net tax cost of trade policy:

$$
\text { Cost }_{t}=\zeta_{t} S_{t}-v_{t}^{M} M_{t}-v_{t}^{X} X_{t}
$$

Using (9) and (23), social welfare can be simplified to

$$
W_{t}=\mathrm{E}_{t} \sum_{i=0}^{\infty} \beta^{i}\left\{\frac{v\left(P_{t+i}, Y\right)-v\left(\tilde{P}_{t+i}^{t}, Y\right)}{w_{t}}+P_{t+i} A_{t+i}-\left(P_{t+i}+k\right) S_{t+i}+v_{t+i}^{M} M_{t+i}+v_{t+i}^{X} X_{t+i}\right\} .
$$

The per-unit storage subsidy enters positively into the private agents' profit and negatively in the public cost, so it does not feature directly in the social welfare function.

Although it is theoretically exact, this formulation of social welfare is not easily tractable in a dynamic framework. In particular, this formulation is not amenable to a standard recursive dynamic specification due to the time variability of $w_{t}$. However, this time variability of the expected marginal utility of income is limited in practice and remains second order. For the sake of tractability, $w_{t}$ is thus assumed to be constant over time and equal to its value at $t=0: w_{t} \approx(1-\beta) \mathrm{E}_{0} \sum_{i=0}^{\infty} \beta^{i} v_{Y}\left(\tilde{P}_{i}^{0}, Y\right)=w$. This assumption applies to the simulations presented below.

\section{Optimization problem}

The social welfare function is a natural objective for policy optimization. In stating this problem, policy is assumed to start at period 0 and to be unanticipated. Commitment is unlikely in most countries, especially in developing countries; thus, policy is assumed to be discretionary. Three state-contingent instruments can be used to stabilize prices: a tax on, or a subsidy for, private storage and a trade policy (import and/or export tax or subsidy). The initial state variables are considered to be at their non-stochastic steady-state level (i.e., $A_{0}=1$ and $P_{0}^{w}=1$ ), and initial stocks are assumed to be null.

Although subsidies to private storage have been used (often in the form of interest rate subsidies, see Gardner and López 1996), storage policies usually take the form of public storage. In many countries, public storage was undertaken by parastatals, which were awarded a monopoly on trade and storage of grains (Rashid, Gulati, and Cummings 2008). An optimal subsidy to private storage can be interpreted as the losses incurred by an efficient monopolistic public agency following an optimal storage rule. In addition, our focus on storage subsidy removes the need to study the interaction between private and public storage, which eliminates a numerical burden.

For the optimal discretionary problem, we assume that there are no reputational mechanisms and focus on Markov-perfect equilibria as defined in Klein, Krusell, and Ríos-Rull (2008) and Ambler and Pelgrin (2010). At each period, optimization entails maximizing the expected sum of the discounted social welfare function subject to the constraints imposed by private agents' behavior and the market equilibrium. The optimization is conducted over current endogenous and control variables, taking the future variables as given: ${ }^{11}$

$$
\max _{\substack{S_{t} \geq 0, P_{t}, M_{t} \geq 0, X_{t} \geq 0, A_{t+1}, \zeta_{t}, v_{t}^{M}, v_{t}^{X}}} \mathrm{E}_{t} \sum_{i=0}^{\infty} \beta^{i}\left\{v\left(P_{t+i}, Y\right)+w\left[P_{t+i} A_{t+i}-\left(P_{t+i}+k\right) S_{t+i}+v_{t+i}^{M} M_{t+i}+v_{t+i}^{X} X_{t+i}\right]\right\},
$$

\footnotetext{
${ }^{11}$ This objective function is obtained from (24) by multiplying the social welfare function by $w$ and subtracting the term independent of policy choice, which reflects the consumer's utility in the situation without intervention, $v\left(\tilde{P}_{t+i}^{t}, Y\right)$.
} 
subject to equations (5)-(7) and (9)-(11), $A_{t}$ and $P_{t}^{w}$ given, and anticipating $\left\{S_{t+i}, P_{t+i}, M_{t+i}, X_{t+i}, A_{t+i+1}\right.$, $\left.\zeta_{t+i}, v_{t+i}^{M}, v_{t+i}^{X}, P_{t+i}^{w}\right\}$ for $i \geq 1$. Because equation (5) involves storers' expectations for the next-period price, this optimization problem is not a standard optimal control problem. This problem is solved, following Klein, Krusell, and Ríos-Rull (2008), by substituting the expected variables with their policy functions. See the supplemental appendix for details.

The above problem defines an optimal stabilization policy using both storage and trade taxes or subsidies. A policy using only one of the two instruments can be easily defined by removing from the objective and the constraints all occurrences of $\zeta$ to define a trade policy or of $v^{M}$ and $v^{X}$ to define a storage policy.

\section{Characterization and consequences of optimal public interventions}

The analytical framework defined above allows optimal public interventions to be characterized. Three cases are considered here, corresponding to the optimal use of trade policy alone, of storage policy alone, and of both policies jointly. We first describe the nature of these policy interventions, and we analyze their consequences for decision rules. We then assess the resulting consequences for welfare.

\section{Optimal trade policy}

In the absence of any storage policy, the optimal use of trade policy can be characterized primarily as comprising two types of interventions. The first intervention consists of subsidizing imports when availability is low.

The corresponding subsidies can be substantial, with powerful trimming impacts on the upper tail of the price distribution. This impact can be observed by comparing the central panels of figures 1(a) and 1(b). Under trade policy, the prices that prevail when importing are lower than without intervention because of the subsidy. Thus, for a small open economy, import subsidies are an efficient way to avoid very high prices. Despite their cost, ad valorem subsidies higher than $15 \%$ are shown to be optimal when domestic scarcity coincides with high world prices. The use of import subsidies may raise questions because they are an uncommon instrument in practice. Import subsidies appear in our framework because our benchmark situation is one of free trade. In practice, even structural food importers tend to maintain positive barriers to trade, motivated by political economy (Grossman and Helpman 1994) or the need to collect fiscal revenue. Given this alternative benchmark of positive tariffs, import subsidies could be interpreted as a tariff reduction for which we have significant evidence (Anderson and Nelgen 2012).

The second type of intervention consists of taxing exports when availability is abundant and world prices are high. These interventions decrease the export parity price and avoid importing the price spikes in the world market via exports. The corresponding tax levels remain moderate, typically lower than 5\%, even for world prices as high as 1.4.

For the asymptotic distribution of prices, this type of optimal trade policy results in a decline in the mean (by $2.4 \%$ ) and a $20 \%$ decrease in the standard deviation (table 2). This reduced variability is strongly asymmetrical, as illustrated by changes in the quantiles; it stems primarily from a heavy reduction in the high prices obtained due to import subsidies and export taxes (the top percentile of the price distribution is driven down from 1.63 without a policy to 1.41 , a decrease of one-third in the deviation from the average price). The 
asymmetry that is typical of price distributions for storable commodities is greatly reduced, with a skewness that is half that of the benchmark.

Table 2: Descriptive statistics on the asymptotic distribution

\begin{tabular}{lcccc}
\hline & Benchmark & Trade policy & Storage subsidy & Both instruments \\
\hline Price & & & & \\
$\quad$ Mean & 1.045 & 1.020 & 1.054 & 1.034 \\
$\quad$ Coefficient of variation & 0.173 & 0.141 & 0.159 & 0.121 \\
$\quad$ Skewness & 1.248 & 0.641 & 1.524 & 0.995 \\
$\quad$ Correlation coefficient & & & & -0.482 \\
$\quad$ with domestic shocks & -0.474 & -0.569 & -0.414 & 0.780 \\
$\quad$ with world price & 0.788 & 0.729 & 0.807 & 0.837 \\
Quantiles & & & & 0.942 \\
$\quad 1 \%$ & 0.790 & 0.787 & 0.837 & 1.008 \\
$25 \%$ & 0.915 & 0.900 & 0.940 & 1.100 \\
$50 \%$ & 1.000 & 1.015 & 1.001 & 1.406 \\
$75 \%$ & 1.131 & 1.107 & 1.123 & 0.047 \\
$\quad 99 \%$ & 1.628 & 1.410 & 1.625 & 0.018 \\
Mean stocks & 0.033 & 0.027 & 0.048 & 0.028 \\
Mean imports & 0.018 & 0.021 & 0.016 & 0.031 \\
Mean export & 0.028 & 0.024 & & \\
\hline
\end{tabular}

Note: All statistics are calculated as the unconditional moments over the asymptotic distribution.

Not surprisingly, these trade policy interventions result in increased imports and decreased exports. Trimming the upper tail of the price distribution also reduces the profitability of storage. As a result, the storage rule is moved to the right, and the mean stock level is reduced by approximately $20 \%$ in the asymptotic distribution.

\section{Optimal storage policy}

In a closed economy, an optimal storage policy motivated by consumer risk aversion under incomplete insurance markets increases the level of storage compared to the situation without intervention (Gouel 2013). In the present context of a small open economy without trade policy intervention, this increase in storage holds when storage does not compete directly with exporting - that is, when the domestic price remains above the export parity price because availability is limited and/or the world price is not overly high. In this case, the storage subsidy increases both storage and the domestic price, contributing to a smoothing of the intertemporal price variability in the domestic market.

To understand the optimal storage subsidy, it should be noted that storage has two effects on prices that occur at different moments: stock accumulation increases the current price, whereas the subsequent stock release decreases price when it occurs. Because of consumers' risk aversion, the optimal policy tends to stabilize the domestic price around its mean. Increasing stock levels may contribute to this objective of stabilization, particularly when the current price is below average and the expected price is above average, but this is not always the case. For a world price that is equal to 1.1 and for intermediate availabilities (between 1 and 1.2), storage occurs when exports are not profitable (see figure 1(c)). In this situation, storage is subsidized until the domestic price reaches the export parity price. At this point, it becomes optimal to tax 
storage. Because the current domestic price is stuck at export parity, storage has no immediate effect, and additional storage would only depress the future price, which is already expected to be below its average value. Therefore, taxing private storage does not affect the current price but raises the expected price closer to the mean. Hence, a discontinuity is observed in the storage rule and in the export curve for availability around 1.1. Beyond this level, storage coexists with trade, and the optimal policy remains a storage tax (worth approximately $3 \%$ of steady-state price). This outcome is paradoxical: public intervention is motivated by consumer risk aversion, but it tends to discourage storage. Intuitively, this is a context of overly abundant availability, in which dispensing with the good through export is socially preferable to retaining it through storage, even if the storer would break even.

When storage and export coexist, there is not always a storage tax. For high world prices (and therefore relatively high domestic prices), storage profitability is quickly driven down to zero. Therefore, additional storage does not affect the current price but brings the expected price closer to its average, which justifies subsidizing storage.

The impact of this type of optimal storage policy on the asymptotic price distribution is strongly constrained by foreign trade. As soon as a country exports or imports, its domestic price is determined by the world price because it is assumed that no trade policy intervention takes place. There are two main channels through which this optimal storage policy influences domestic prices. First, storage subsidies increase domestic prices in situations of stock accumulation when above-average availability is combined with a low to intermediate world price, with the exception of the above-mentioned case of a storage tax when storage coexists with exports. Second, the ensuing higher stock levels decrease prices when stocks are sold, but this situation often coincides with situations of international trade, thus limiting the price fall.

As a result, the optimal public storage policy increases the mean price of the asymptotic distribution (see table 2). This increase appears paradoxical because the standard result obtained for a closed economy is that introducing private storage or increasing levels of storage through public intervention depresses the average prices (Gouel 2013; Miranda and Helmberger 1988; Wright and Williams 1982a). To interpret this puzzling result, it is useful to consider this stabilization policy through storage as a sequence of transfers of demand from one period $t_{1}$ to another $t_{2}$, when the price is higher $\left(p_{1}<p_{2}\right)$, as suggested by Newbery and Stiglitz (1981, p. 251, theorem 2). Consumers' demand is reduced by any additional storage, and it is increased by the same amount (in the absence of spoilage) when the quantity stored is finally sold. To see how the demand transfer influences prices, let us differentiate the market clearing equation (11) with regard to stocks:

$$
D^{\prime}\left(P_{t}\right) \frac{\partial P_{t}}{\partial S_{t}}+1+\frac{\partial\left(X_{t}-M_{t}\right)}{\partial S_{t}}=0
$$

In a closed economy, the last term is pointless, and this equation collapses to $\partial P_{t} / \partial S_{t}=-1 / D^{\prime}\left(P_{t}\right)$. As soon as the demand function is convex, as in the case of a constant elasticity function, this partial derivative is an increasing function of prices, meaning that it is larger in $t_{2}$ than in $t_{1}$. As a result, modifying storage to operate a small transfer of consumption from $t_{1}$ to $t_{2}$ would cut the price in $t_{2}$ by more than it would increase it in $t_{1}$. This result explains why stabilization through additional storage usually depresses the mean prices in a closed economy.

In an open economy, in contrast, the last term on the left-hand side of (26) is not zero. It may be the case that the country exports when the consumption transfer occurs. In this case, a small enough level of additional storage will not drive exports to zero, meaning that it will not change the domestic price, which will remain equal to the world price minus the transport cost. Conversely, when there is trade, selling additional stocks does not depress the domestic price. This latter effect dominates in practice, primarily because it means that 
the country cannot insulate its market from episodes of very high world prices. In this case, domestic stocks are sold on the world market (either directly or indirectly, when the domestic consumption of domestic stocks displaces imports). The sale of domestic stocks is profitable given the high price level, but it does not curb domestic prices. Hence, a storage policy has limited efficiency to avoid high-price episodes.

Although this optimal storage policy reduces the standard deviation of prices by approximately $7 \%$, stabilization comes only from the increase in low prices; this is a paradoxical result for a public intervention that is linked to consumer welfare. The upper quantiles of the asymptotic price distribution change little compared to the benchmark, whereas the first percentile increases by 6\% (table 2).

The impact on trade is not trivial. The significantly higher average stock reduces the frequency of scarce domestic availability and the associated large imports. On average, imports are reduced by $11 \%$. For the same reason, abundant availabilities are more frequent, and they increase exports. When storage coincides with exports, this export-enhancing effect is magnified by the storage tax mentioned above, which reduces the demand for storage, thus increasing the volumes of domestic output absorbed by the world market. On average, exports increase by $11 \%$. This increased importance of exports is also a strong driver of domestic price variability, as illustrated by the increased correlation between domestic and world prices. On the whole, and despite the absence of trade policy, this policy could be considered opportunistic in trade terms to the extent that the country tends to favor storage when world prices are low but to discourage it when they are sufficiently high.

\section{Optimal trade and storage policy}

Optimally combining trade and storage policies enables a powerful stabilization policy that cuts the standard deviation of domestic prices by more than a quarter compared to the benchmark. This result is not surprising given that trade policy is very efficient at preventing domestic prices from reaching high levels, and storage is a powerful tool to avoid excessively low prices. The basis of an optimal policy mix is thus the use of import subsidies and export taxes to trim the upper tail of the distribution of domestic prices and storage subsidies to trim the lower tail. The reduced variability of domestic prices comes from both ends of the distribution, which move substantially closer to the mean than in the benchmark (see quantiles in table 2). This outcome is comparable to the outcome obtained with a storage policy for lower quantiles and with a trade policy for upper quantiles.

However, the instruments are not independent, and their interrelationships are especially strong when the country both exports and stores, as in the case of abundant availability under intermediate world prices (1.1 in figure 1(d)). When both instruments are combined, the optimal policy consists of subsidizing exports while subsidizing storage (for a world price of 1.1 , the per-unit subsidy $\zeta$ is 0.04 , or $4 \%$ of the steady-state domestic price). Despite lower stocks, the result is a domestic price beyond the price that would prevail without intervention (i.e., closer to the distribution mean). This shift contributes to limiting price variability. For a higher world price, however, private storage is still subsidized but exports are taxed, which prevents domestic prices from reaching excessive levels.

The mean price of the asymptotic distribution is slightly lower than in the benchmark; this outcome is between the outcomes for trade and storage policies. The price is also intermediate in terms of the correlation of domestic prices with world prices and with domestic shocks. The impact on foreign trade appears to be intermediate between the impacts of each instrument individually, with a slight increase in mean imports and a slight decrease in mean exports. Although it is interventionist and entails potentially significant export taxes, on average, such an optimal policy is not trade restrictive. 
This optimal policy leads to an average price transmission elasticity of 0.63 (obtained by regressing the logarithm of domestic price on the logarithm of border prices for non zero trade). This elasticity is consistent with the econometric evidence. For instance, Anderson and Nelgen (2012) find that for 75 countries, the average short-run price transmission elasticities are $0.52,0.47,0.57$, and 0.72 for rice, wheat, maize, and soybeans, respectively. However, contrary to the events of the recent food crisis, the optimal policy never involves a complete export ban.

\section{Decomposition of welfare changes}

By changing the distributions of prices, stabilization policies transfer both risks and resources across agents. To understand the distributive effects of these policies, the welfare change for each agent is illustrated for the three optimal policies in table 3. This illustration is performed on the transitional dynamics, meaning that the values are the expected welfare values when beginning the policy at period 0 .

Table 3: Welfare results of optimal policies on transitional dynamics (as percentage of the steady-state commodity budget share)

\begin{tabular}{lccc}
\hline & Trade policy & Storage subsidy & Both instruments \\
\hline Consumers & 2.47 & -0.94 & 1.05 \\
Producers & -2.53 & 1.08 & -0.92 \\
Government & 0.12 & -0.12 & -0.03 \\
$\quad$ Storage subsidy & - & -0.12 & -0.17 \\
Trade policy & 0.12 & - & 0.14 \\
Total & 0.06 & 0.03 & 0.10 \\
\hline
\end{tabular}

Consumer gains are given by the ex ante per-period equivalent variation, $E V_{0}$ (defined in (20)). Producers are not explicitly represented because production is defined by exogenous stochastic shocks, but they are affected by policies through price changes. Their welfare change is defined by their average change in benefits: $\mathrm{E}_{0} \sum_{t=0}^{\infty} \beta^{t} \Delta\left(P_{t} \varepsilon_{t}^{H}\right)$. Government outlays are the annualized expected sum of discounted costs defined by equation (23). ${ }^{12}$ The changes in storers' surpluses are ignored because the storers operate, on average, at zero profit, and we assume no stock at the first period.

It is striking that the total gains are small in comparison to the distributive effects. To protect consumers from price fluctuations, public intervention induces comparatively large changes for producers. These transfers stem primarily from two effects. The first is the change in the mean price; a lower mean price, as a result of the optimal use of trade policy or both instruments, benefits consumers at the expense of producers. The reverse is true under storage policy alone. Changes in the covariance between prices and production shocks also initiate transfers between producers and consumers, but their importance is more limited. The fiscal cost of the policies is an additional source of transfer; trade policy intervention generates fiscal revenue, whereas storage subsidies entail costs. Although these fiscal effects are limited compared to the effects on producers, their magnitude is higher than the total gains.

Consumers' gains comprise three components that are not decomposed in table $3 .^{13}$ The first two

\footnotetext{
${ }^{12}$ Welfare terms are all discounted infinite sums. These terms are calculated by transformation to a recursive formulation and value function iteration.

${ }^{13}$ See Newbery and Stiglitz (1981, Ch. 6 and 9) for a discussion of efficiency and transfer gains from price stabilization. The corresponding decomposition is performed in the working paper version of this article (Gouel and Jean 2012)
} 
components are contained in consumers' surplus: a transfer term corresponding to the change in mean expenditure and the efficiency gains originating in the change in mean consumption (i.e., the traditional welfare triangle in a surplus analysis). The third component is the welfare change originating from consumers' risk aversion. This latter component is necessarily positive because instability decreases with all policies, whereas the first two might be positive or negative depending on the change in the price distribution and, in particular, the mean price change, which reveals the mean expenditure and the mean consumption change.

An optimal storage subsidy without trade policy intervention has counter-intuitive impacts. Although public intervention is motivated by consumers' risk aversion, it actually results in losses for consumers. Decreased price volatility is more than compensated for by reduced mean consumption due to higher prices. The policy is still socially beneficial because of efficiency gains stemming from the risk reduction, but it does not increase consumers' welfare. In the absence of trade policy, a storage subsidy makes consumers worse off because stocks are mostly accumulated when prices are affected by stock accumulation, but they are sold when the economy is connected to the world market (see the effect on quantiles in table 2). ${ }^{14}$

With an optimal trade policy, consumers enjoy significant gains that result from decreases in both the mean price and price variability, especially from less frequent price spikes. However, these gains are at the cost of significant transfers from producers. The order of magnitude of both effects is $2.5 \%$, with a net gain to the economy of $0.06 \%$.

Although the effects of an optimal combination of trade and storage policies are intermediate between single-instrument policies, these effects are closer to the impacts of trade policy. Consumers enjoy gains that primarily reflect the policy's effectiveness at preventing price spikes, and the cost is a deterioration in producers' welfare. However, public intervention is more effective in this case; consumers' gains reach 1\%, whereas total social gains reach $0.1 \%$. With smaller transfers, this policy achieves greater gains. This finding illustrates the strong complementarity between trade and storage policies.

\section{Consequences of a discipline on export restrictions}

The use of trade policies to manage price volatility is potentially problematic because these are noncooperative policies with potential negative consequences for partner countries. In particular, when a country uses a trade policy to insulate its domestic market from extreme world price values, its action may further increase world prices. If all trading countries apply this policy, the collective-action problem may reach the point where individual countries' efforts to insulate themselves from high world prices cancel each other out (Martin and Anderson 2012). The use of export restrictions during the 2007-08 food crisis epitomizes this concern. Export restrictions played a significant role in price upsurges and spurred calls for multilateral discipline in the use of these instruments (Mitra and Josling 2009, is an example).

The small open economy setup adopted here does not allow for an explicit analysis of the problem in terms of international cooperation. Nonetheless, this problem is rooted in distorted excess supply curves in countries that undertake price-insulation policies, and these curves can be characterized based on the expected value of net exports for a given world price level. Based on the asymptotic distribution, these curves are plotted in figure 3 for the benchmark case of no policy intervention and under different optimal policy settings. On its own, an optimal trade policy decreases excess supply for all world prices. The deviation is significant for world prices above 1.2, confirming that the use of trade policy may exacerbate high world

\footnotetext{
${ }^{14}$ This result is similar in spirit to Myers's (1988) result: completing the market when producers are risk averse generates aggregate welfare gains but may decrease producers' welfare because risk reduction leads to a supply response and a subsequent mean price decrease.
} 
price episodes. However, when trade policy is optimally combined with storage policy, deviations from the benchmark are less pronounced. The expected excess supply is significantly reduced only for world prices above 1.35, and it is slightly increased for intermediate world price levels due to the positive effect of storage policy on asymptotic availability. The latter effect explains why excess supply always increases when only a storage policy is applied.

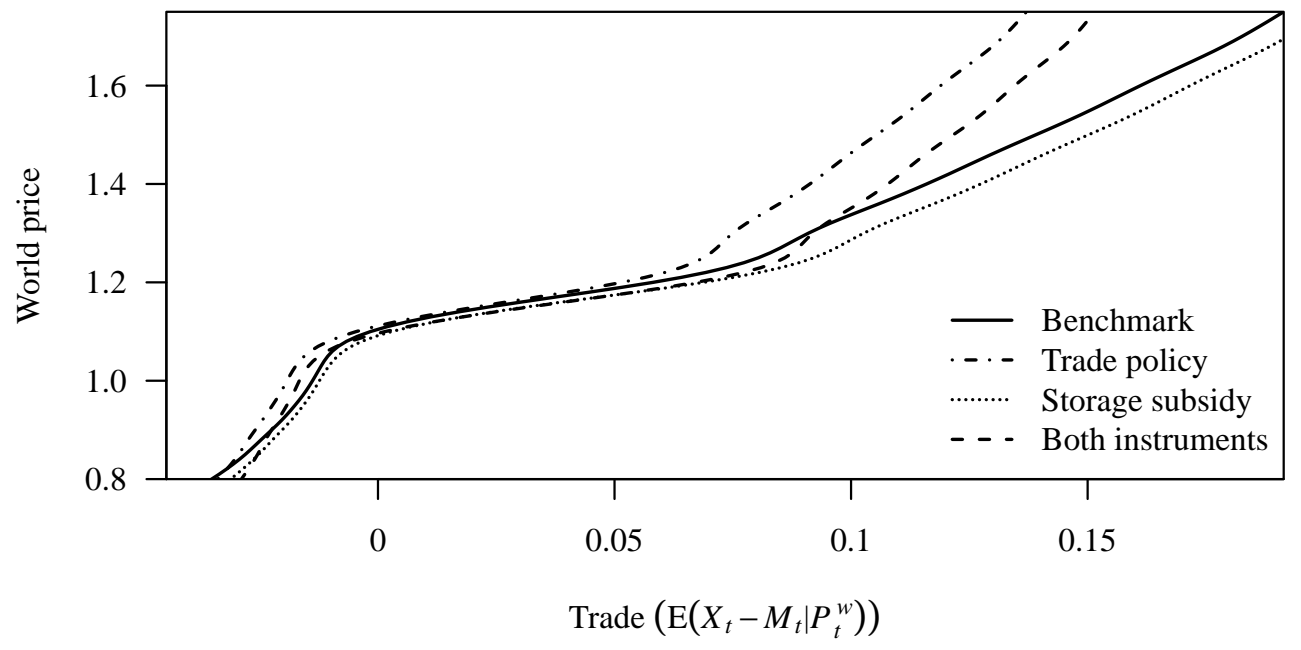

Figure 3: Asymptotic excess supply curves (smoothing splines of the trade-world price relationship over $1,000,000$ observations of the asymptotic distribution)

These results confirm that trade policy intervention may significantly distort excess supply curves. This effect is especially true for high prices, reflecting the use of export taxes. Thus, it makes sense to consider multilateral discipline on export restrictions. To evaluate what is at stake in the case of such discipline, we assess the consequences for a developing country of deviating from its optimal policy by committing to not using any export restrictions (given the existing disciplines, we also assume that export subsidies are prohibited).

Banning export taxes prevents the country from insulating itself against high world prices when domestic availability is large enough. This ban substantially increases the occurrence of high domestic prices, with an upper tail of price distribution closer to the no-intervention benchmark than to the undisciplined optimal policy (the 1, 25, 50, 75, and 99 quantiles are, respectively, at 0.84, 0.94, 1.00,1.11, and 1.61). Because the optimal storage subsidy decreases the occurrence of low prices by increasing stock levels, the overall effect is a slight increase in the mean price (up to 1.048) compared to the benchmark rather than a decline resulting from an undisciplined optimal policy.

With a limited decrease in volatility (the coefficient of variation of the domestic price is 0.15 ), the welfare effects on consumers are dominated by the increased mean price, so consumers lose as a result of this policy, as in the case of storage policy only. Export disciplines thus entail significant transfers from consumers to producers. Overall, the gains for the entire economy are more than halved compared to the undisciplined optimal policy. In sum, export taxes appear to be key components of price-stabilizing policies that benefit consumers. The stakes for possible multilateral disciplines on export restrictions would be high for a number of poor countries. 


\section{Conclusion}

To analyze the use of trade and storage policies to achieve food price stabilization, this paper relies upon a rational expectations storage model. Our analysis focuses on the design of optimal policies in a small developing economy where public intervention is justified by a lack of insurance against price volatility for risk-averse consumers. To our knowledge, this is the first attempt to design optimal dynamic food price stabilization policies in an open economy setting. The model can only be solved numerically, and tractability requires simple specification, so the model ignores the supply reaction and producers' risk aversion. However, the framework developed here could be applied to other cases in terms of both its parametrization and its specification.

Our results show that for the case of a normally self-sufficient country, an optimal trade policy in the presence of risk aversion includes subsidizing imports and taxing exports during periods of high domestic prices. ${ }^{15}$ This policy truncates the upper half of the distribution and is not fiscally costly because the proceeds from export taxation cover the fiscal cost of import subsidies. Import subsidies alleviate the traditional limit of food storage (i.e., its non-negativity). When stocks are zero, subsidizing imports prevents price spikes.

When stabilization is pursued through storage subsidies only, it does not improve consumers' welfare. Additional storage increases low prices through additional demand for stockpiling, but it is not effective at preventing price spikes. In a small open economy, price spikes often occur when the world price is high, in which case any additional stock is sold on the world market. Although domestic prices are stabilized to some extent, the potential benefits for consumers are eliminated by the increase in the mean price. This type of policy improves the country's trade balance by giving it more resources to export when the world price is relatively high, but it does not benefit consumers. Because storage policies are generally seen as a way to help consumers, these results indicate that storage policies designed without flanking trade policy might be inconsistent. The limited insulation provided by trade costs—especially when they are relatively small—does not allow for the pursuit of any independent food price policy. In contrast, a well-designed combination of trade and storage taxes and subsidies can be a cost-efficient price-stabilizing policy.

These policies have an important common limitation: they produce distributive welfare effects that are much larger than the total gains. Reducing consumers' risk bearing by manipulating prices in an open economy may thus face strong opposition. Although social assistance programs might be used to mitigate these distributional impacts, this result emphasizes the drawbacks of stabilization policies compared to policies that specifically target poor households.

Our results show that an optimal combination of trade and storage policies trims both the lower and the upper parts of the domestic price distribution. Thus, the optimal policy identified here should remain welfare increasing even when producers are risk averse because they should value the trimming of low prices. The same goes for the issue of supply elasticity: because expected prices are not strongly modified, supply reaction should remain limited.

We find that export taxes are important for designing price-stabilizing policies that benefit consumers. This result should not be understood as a plea for export restrictions, the destabilizing effects of which are well documented and are a legitimate and serious source of concern at the multilateral level (Mitra and Josling 2009). Nonetheless, this analysis might provide a better understanding of why export restrictions are such a frequent occurrence. This analysis might also help to gauge the stakes of potential multilateral disciplines. Particularly for the poorest countries, banning export restrictions altogether may be politically difficult, at

\footnotetext{
${ }^{15}$ Sensitivity to the assumption of self-sufficiency is analyzed in a supplemental appendix.
} 
least if no substantial compensating measures are offered. The collective action problem created by export restrictions certainly deserves closer scrutiny. In any case, these constraints, disturbing as they are, are better acknowledged than ignored.

\section{Funding}

This work was supported by the $7^{\text {th }}$ Framework Programme for Research and Development, DG-Research, European Commission [AgFoodTrade:212036 and FOODSECURE:290693], and the Knowledge for Change Program.

\section{References}

Ambler, Steve and Florian Pelgrin. 2010. "Time-consistent control in non-linear models". Journal of Economic Dynamics and Control 34 10: 2215-28.

Anderson, James E. and John G. Riley. 1976. "International Trade with Fluctuating Prices". International Economic Review 17 1: 76-97.

Anderson, Kym and Signe Nelgen. 2012. "Trade Barrier Volatility and Agricultural Price Stabilization”. World Development 40 1: 36-48.

Asian Development Bank. 2008. Food Prices and Inflation in Developing Asia: Is Poverty Reduction Coming to an End? Special report. Manila: ADB, Economics and Research Department.

Babcock, Bruce A. and David A. Hennessy. 1996. "Input Demand under Yield and Revenue Insurance". American Journal of Agricultural Economics 78 2: 416-27.

Bagwell, Kyle and Alan O. Sykes. 2004. "Chile - Price Band System and Safeguard Measures Relating to Certain Agricultural Products". World Trade Review 3 03: 507-28.

Batra, Raveendra N. and William R. Russell. 1974. "Gains from Trade Under Uncertainty". The American Economic Review 64 6: 1040-8.

Bigman, David and Shlomo Reutlinger. 1979. "Food Price and Supply Stabilization: National Buffer Stocks and Trade Policies". American Journal of Agricultural Economics 61 4: 657-67.

Bouët, Antoine and David Laborde Debucquet. 2012. "Food crisis and export taxation: the cost of noncooperative trade policies". Review of World Economics 148 1: 209-33.

Brainard, William C. and Richard N. Cooper. 1968. "Uncertainty and Diversification in International Trade". Food Research Institute Studies 8: 257-85.

Braun, Joachim von. 2008. Rising food prices: What should be done? Policy Brief 1. IFPRI.

Brennan, Donna. 2003. "Price dynamics in the Bangladesh rice market: implications for public intervention". Agricultural Economics 29 1: 15-25.

Cafiero, Carlo, Eugenio S. A. Bobenrieth, Juan R. A. Bobenrieth, and Brian D. Wright. 2011. "The Empirical Relevance of the Competitive Storage Model". Journal of Econometrics 162 1: 44-54.

Cassing, James H., Arye L. Hillman, and Ngo Van Long. 1986. "Risk Aversion, Terms of Trade Uncertainty and Social-Consensus Trade Policy". Oxford Economic Papers 38 2: 234-42.

Coleman, Andrew. 2009. "Storage, Slow Transport, and the Law of One Price: Theory with Evidence from Nineteenth-Century U.S. Corn Markets". Review of Economics and Statistics 91 2: 332-50.

Deaton, Angus and Guy Laroque. 1992. "On the Behaviour of Commodity Prices". Review of Economic Studies 59 1: 1-23. 
Dixit, Avinash. 1987. "Trade and insurance with moral hazard". Journal of International Economics 23 3-4: 201-20.

- . 1989. "Trade and Insurance with Adverse Selection". Review of Economic Studies 56 2: 235-47.

Dorosh, Paul A. 2008. "Food Price Stabilisation And Food Security: International Experience". Bulletin of Indonesian Economic Studies 44 1: 93-114.

— . 2009. "Price stabilization, international trade and national cereal stocks: world price shocks and policy response in South Asia". Food Security 12 : 137-49.

Eaton, Jonathan and Gene M. Grossman. 1985. "Tariffs as Insurance: Optimal Commercial Policy When Domestic Markets Are Incomplete". The Canadian Journal of Economics 18 2: 258-72.

Feder, Gershon, Richard E. Just, and Andrew Schmitz. 1977. "Storage with Price Uncertainty in International Trade". International Economic Review 18 3: 553-68.

Feenstra, Robert C. 1987. "Incentive Compatible Trade Policies". English. The Scandinavian Journal of Economics 89 3: 373-87.

Gardner, Bruce L. and Ramón López. 1996. "The Inefficiency of Interest-Rate Subsidies in Commodity Price Stabilization". American Journal of Agricultural Economics 78 3: 508-16.

Gollier, Christian. 2010. "Expected net present value, expected net future value, and the Ramsey rule". Journal of Environmental Economics and Management 59 2: 142-8.

Gouel, Christophe. 2013. "Optimal food price stabilisation policy”. European Economic Review 57: 118-34.

Gouel, Christophe and Sébastien Jean. 2012. Optimal Food Price Stabilization in a Small Open Developing Country. Policy Research Working Paper 5943. URL: http://go worldbank org/23I9ACR4R0. The World Bank.

Grossman, Gene M. and Elhanan Helpman. 1994. "Protection for Sale". The American Economic Review 84 4: 833-50.

Hausman, Jerry A. 1981. "Exact Consumer's Surplus and Deadweight Loss". The American Economic Review 71 4: 662-76.

Headey, Derek. 2011. "Rethinking the global food crisis: The role of trade shocks". Food Policy 36 2: 136-46.

Helms, L. Jay. 1985a. "Errors in the Numerical Assessment of the Benefits of Price Stabilization". American Journal of Agricultural Economics 67 1: 93-100.

— . 1985b. "Expected Consumer's Surplus and the Welfare Effects of Price Stabilization". International Economic Review 26 3: 603-17.

Helpman, Elhanan and Assaf Razin. 1978. A Theory of International Trade under Uncertainty. New York: Academic Press: p. 185.

Islam, Nurul and Saji Thomas. 1996. Foodgrain Price Stabilization in Developing Countries: Issues and Experiences in Asia. Food Policy Review 3. IFPRI.

Klein, Paul, Per Krusell, and José-Víctor Ríos-Rull. 2008. “Time-Consistent Public Policy”. Review of Economic Studies 75 3: 789-808.

Korinek, Jane and Patricia Sourdin. 2010. "Clarifying Trade Costs: Maritime Transport and Its Effect on Agricultural Trade". Applied Economic Perspectives and Policy 32 3: 417-35.

Larson, Donald F., Julian Lampietti, Christophe Gouel, Carlo Cafiero, and John Roberts. 2014. "Food security and storage in the Middle East and North Africa". World Bank Economic Review 28 1: 48-73.

Makki, Shiva S., Luther G. Tweeten, and Mario J. Miranda. 1996. "Wheat Storage and Trade in an Efficient Global Market". American Journal of Agricultural Economics 78 4: 879-90.

— . 2001. "Storage-trade interactions under uncertainty-Implications for food security". Journal of Policy Modeling 23 2: 127-40. 
Martin, Will and Kym Anderson. 2012. "Export Restrictions and Price Insulation During Commodity Price Booms". American Journal of Agricultural Economics 94 1. ASSA Meeting Invited Paper Session: 422-7. Miranda, Mario J. and Joseph W. Glauber. 1995. "Solving Stochastic Models of Competitive Storage and Trade by Chebychev Collocation Methods". Agricultural and Resource Economics Review 24 1: 70-7.

Miranda, Mario J. and Peter G. Helmberger. 1988. "The Effects of Commodity Price Stabilization Programs". The American Economic Review 78 1: 46-58.

Mitra, Siddhartha and Tim Josling. 2009. Agricultural Export Restrictions: Welfare Implications and Trade Disciplines. Position Paper Agricultural and Rural Development Policy. IPC.

Myers, Robert J. 1988. "The Value of Ideal Contingency Markets in Agriculture”. American Journal of Agricultural Economics 70 2: 255-67.

Nelson, Carl H. and Paul V. Preckel. 1989. "The Conditional Beta Distribution as a Stochastic Production Function". American Journal of Agricultural Economics 71 2: 370-8.

Newbery, David M. G. and Joseph E. Stiglitz. 1981. The Theory of Commodity Price Stabilization: A Study in the Economics of Risk. Oxford: Clarendon Press.

— . 1984. "Pareto Inferior Trade". Review of Economic Studies 51 1: 1-12.

Pelcovits, Michael D. 1979. "The equivalence of quotas and buffer stocks as alternative stabilization policies". Journal of International Economics 9 2: 303-7.

Rashid, Shahidur, Ashok Gulati, and Ralph Waldo Cummings, eds. 2008. From Parastatals to Private Trade: Lessons from Asian Agriculture. Baltimore, Md.; Washington D.C.: Johns Hopkins University Press ; International Food Policy Research Institute.

Reutlinger, Shlomo and Keith C. Knapp. 1980. Food Security in Food Deficit Countries. Staff Working Paper 393. The World Bank.

Ricardo, David. 1821. The Principles of Political Economy and Taxation. 3rd. reprinted 2004. New York: Dover Publications.

Seale Jr., James L. and Anita Regmi. 2006. "Modeling International Consumption Patterns". Review of Income and Wealth 52 4: 603-24.

Slayton, Tom. 2009. Rice Crisis Forensics: How Asian Governments Carelessly Set the World Rice Market on Fire. Working Paper 163. Center for Global Development.

Srinivasan, P. V. and Shikha Jha. 2001. "Liberalized trade and domestic price stability. The case of rice and wheat in India". Journal of Development Economics 65 2: 417-41.

Teisberg, Thomas J. 1981. “A Dynamic Programming Model of the U.S. Strategic Petroleum Reserve”. The Bell Journal of Economics 12 2: 526-46.

Timmer, C. Peter. 1989. "Food price policy: The rationale for government intervention". Food Policy 14 1: $17-27$.

Turnovsky, Stephen J. 1974. "Technological and Price Uncertainty in a Ricardian Model of International Trade". Review of Economic Studies 41 2: 201-17.

Williams, Jeffrey C. and Brian D. Wright. 1991. Storage and Commodity Markets. New York: Cambridge University Press: p. 518.

World Bank. 2007. World Development Report 2008. Agriculture for Development. Washington, DC: The World Bank.

Wright, Brian D. 2001. “Storage and price stabilization”. In: Marketing, Distribution and Consumers. Ed. by Bruce L. Gardner and Gordon C. Rausser. Vol. 1B, part 2. Handbook of Agricultural Economics. Amsterdam: Elsevier. Chap. 14: pp. 817-861.

Wright, Brian D. and Carlo Cafiero. 2011. "Grain reserves and food security in the Middle East and North Africa". Food Security 3 Supplement 1: 61-76. 
Wright, Brian D. and Jeffrey C. Williams. 1982a. "The Economic Role of Commodity Storage". The Economic Journal 92 367: 596-614.

— . 1982b. "The Roles of Public and Private Storage in Managing Oil Import Disruptions". The Bell Journal of Economics 13 2: 341-53. 